\title{
Differences in P-glycoprotein activity in human and rodent blood-brain barrier assessed by mechanistic modelling
}

\author{
Laurens F. M. Verscheijden $^{1}$ (D) Jan B. Koenderink ${ }^{1}$ (D) . Saskia N. de Wildt ${ }^{1,2}$ (D) Frans G. M. Russel $^{1}$ (D)
}

Received: 3 May 2021 / Accepted: 29 June 2021 / Published online: 15 July 2021

(c) The Author(s) 2021

\begin{abstract}
Variation in the efficacy and safety of central nervous system drugs between humans and rodents can be explained by physiological differences between species. An important factor could be P-glycoprotein (Pgp) activity in the blood-brain barrier (BBB), as BBB expression of this drug efflux transporter is reportedly lower in humans compared to mouse and rat and subject to an age-dependent increase. This might complicate animal to human extrapolation of brain drug disposition and toxicity, especially in children. In this study, the potential species-specific effect of BBB Pgp activity on brain drug exposure was investigated. An age-dependent brain PBPK model was used to predict cerebrospinal fluid and brain mass concentrations of Pgp substrate drugs. For digoxin, verapamil and quinidine, in vitro kinetic data on their transport by Pgp were derived from literature and used to scale to in vivo parameters. In addition, age-specific digoxin transport was simulated for children with a postnatal age between 25 and 81 days. BBB Pgp activity in the model was optimized using measured CSF data for the Pgp substrates ivermectin, indinavir, vincristine, docetaxel, paclitaxel, olanzapine and citalopram, as no useful in vitro data were available. Inclusion of Pgp activity in the model resulted in optimized predictions of their brain concentration. Total brain-to-plasma AUC values (Kp,brain) in the simulations without Pgp were divided by the Kp,brain values with Pgp. Kp ratios ranged from 1 to 45 for the substrates investigated. Comparison of human with rodent Kp,brain ratios indicated $\geq$ twofold lower values in human for digoxin, verapamil, indinavir, paclitaxel and citalopram and $\geq$ twofold higher values for vincristine. In conclusion, BBB Pgp activity appears species-specific. An age-dependent PBPK modelbased approach could be useful to extrapolate animal data to human adult and paediatric predictions by taking into account species-specific and developmental BBB Pgp expression.
\end{abstract}

Keywords Physiologically based pharmacokinetic modelling $\cdot$ P-glycoprotein $\cdot$ Species differences $\cdot$ Blood-brain barrier $\cdot$ Paediatric $\cdot$ Brain

\section{Introduction}

Rodent studies are performed during non-clinical development of drug candidates for the assessment of their effectivity and safety. Detection of central nervous system toxicity is not always sensitive enough, as it remains one of the main causes for discontinuation due to safety reasons in the

Frans G. M. Russel

Frans.Russel@radboudumc.nl

1 Department of Pharmacology and Toxicology, Radboud Institute for Molecular Life Sciences, Radboud University Medical Center, Nijmegen, The Netherlands

2 Intensive Care and Department of Paediatric Surgery, Erasmus MC-Sophia Childrens Hospital, Rotterdam, The Netherlands clinical phase of drug development (Weaver and Valentin 2019). In chemical risk assessment, potentially neurotoxic agents are tested in rodents, but findings cannot always be extrapolated to humans (Krewski et al. 2010). Species differences between rodents and humans are the reason for the lack of predictive value and can result from both altered characteristics in pharmacokinetics as well as mode of action (Jones et al. 2013).

Blood-brain barrier (BBB) function is an important factor mediating neurotoxicity. The efflux transporter P-glycoprotein (Pgp) is a major player in restricting brain access to xenobiotics, as indicated by mice knockout studies and human drug-drug interaction studies (Bauer et al. 2015; Morris et al. 2017; Xie et al. 1999). Species differences in Pgp expression and activity could result in an inaccurate estimate of xenobiotic BBB penetration and neurotoxic 
potential. Previous studies suggested that Pgp expression is lower in humans compared to rodents (Al Feteisi et al. 2018; Uchida et al. 2011). In addition, prediction of Pgp activity is complicated by differences in expression between subgroups, as, for instance, Pgp expression in children is lower compared to adults, potentially making this population more susceptible to higher substrate brain exposures (Lam et al. 2015; Verscheijden et al. 2020b).

In vitro-to-in vivo extrapolation (IVIVE) is used to scale in vitro kinetics to parameters that reflect transport in vivo. In vitro transporter activity is corrected for the amount of transporter protein in the in vitro system and multiplied with abundance in the tissue (e.g. BBB) of interest (Bhatt et al. 2019; Cheung et al. 2019). This allows predictions of BBB Pgp activity for the human transporter isoform. In addition, predictions for sub-groups such as children are possible by correcting for age-related differences in transporter expression (Verscheijden et al. 2020a). This has previously been used for predicting liver and kidney exposure, and recent studies proposed a similar approach for the brain (Kumar et al. 2018; Li et al. 2017; Neuhoff et al. 2013a; Verscheijden et al. 2021).

Over the last decades, IVIVE in combination with physiologically based toxicokinetic/pharmacokinetic modelling (PBTK/PBPK) has become a versatile tool for first-inhuman dose selection, prediction of DDI's, PK in special populations and prediction of internal organ exposure (Paini et al. 2019; Rose et al. 2014; Shebley et al. 2018; Verscheijden et al. 2020a). An advantage of PBPK modelling is that predictions are based on system-specific properties (also called physiological properties) which are, as much as possible, separated from drug-related properties. This allows the re-use of models for different compounds by changing the drug-related parameters, or extrapolation of models to other populations/species by changing physiological parameters. By this means, models have been extrapolated from animals to humans and from adults to children (Verscheijden et al. 2020a). In addition, due to the multi-compartment structure, models have been used for the prediction of tissue drug concentrations. Including IVIVE parameters in a PBPK model allows for the prediction of brain drug concentrations (Gaohua et al. 2016) and the influence of BBB Pgp activity can be quantified (Li et al. 2017).

In this study, a human PBPK model was used that included blood-brain barrier Pgp activity. Predictions of adult and paediatric brain exposures with and without the inclusion of Pgp were compared with reported brain exposure in rodent wildtype, knockout and Pgp-inhibited animals. By this means, the potential effect of species-specific Pgp-mediated BBB function on differences in observed central nervous system drug exposure was assessed.

\section{Methods}

\section{General human brain PBPK model development}

A 14 compartment PBPK model was developed in Rstudio version 3.6.2 based on a model published previously (Gaohua et al. 2016; Verscheijden et al. 2019, 2021) (Fig. 1). Physiological parameters for body weight, body height, body surface area, organ volumes, tissue blood flows, haematocrit and albumin concentrations were included. Organ-plasma partitioning was estimated using the equations of Rodgers and Rowland, which take into account tissue composition, ionization and lipophilicity of compounds (Online Resource 1) (Rodgers et al. 2005; Rodgers and Rowland 2006). Drug clearance, Kp values and oral absorption rate constants were derived from clinical studies and optimized to capture measured plasma data if necessary (Online Resource 1). The clearance coefficient of variation was set to $30 \%$ for all compounds. Specifically for simulations in children, age-appropriate physiological parameters were included as reported previously (Verscheijden et al. 2019).

The part of the model describing the brain consists of four compartments, representing brain mass, intracranial CSF, spinal CSF, and brain blood (Gaohua et al. 2016; Verscheijden et al. 2019). In short, physiological parameters were included for organ volumes, blood and CSF fluid flows, and BBB and BCSFB surface area (Verscheijden et al. 2019). The BBB is the barrier between brain mass and blood. The blood-CSF barrier is the barrier between the cranial CSF and blood and is assumed to be half of the BBB surface area (Verscheijden et al. 2019). No barrier exists between brain mass and cranial CSF, and between spinal and cranial CSF, which are connected via CSF shuttle flow (Gaohua et al. 2016). All compartments were treated as well stirred. For simulations in children, ageappropriate brain physiological parameters were included as reported previously (Verscheijden et al. 2019).

\section{Parameters for substrates entering the brain by passive diffusion: quetiapine, oxycodone, mirtazapine, etoricoxib, dexketoprofen, lacosamide and ibuprofen}

To confirm that the physiological parameters used in the model are accurate, simulations were performed for quetiapine, oxycodone, mirtazapine, etoricoxib, dexketoprofen, lacosamide and ibuprofen assumed to enter the brain via passive diffusion (Boström et al. 2005; Moons et al. 2011; O'Brien et al. 2013; Schmitt et al. 2012; Uhr et al. 2003). The BBB and BCSFB permeability surface area 


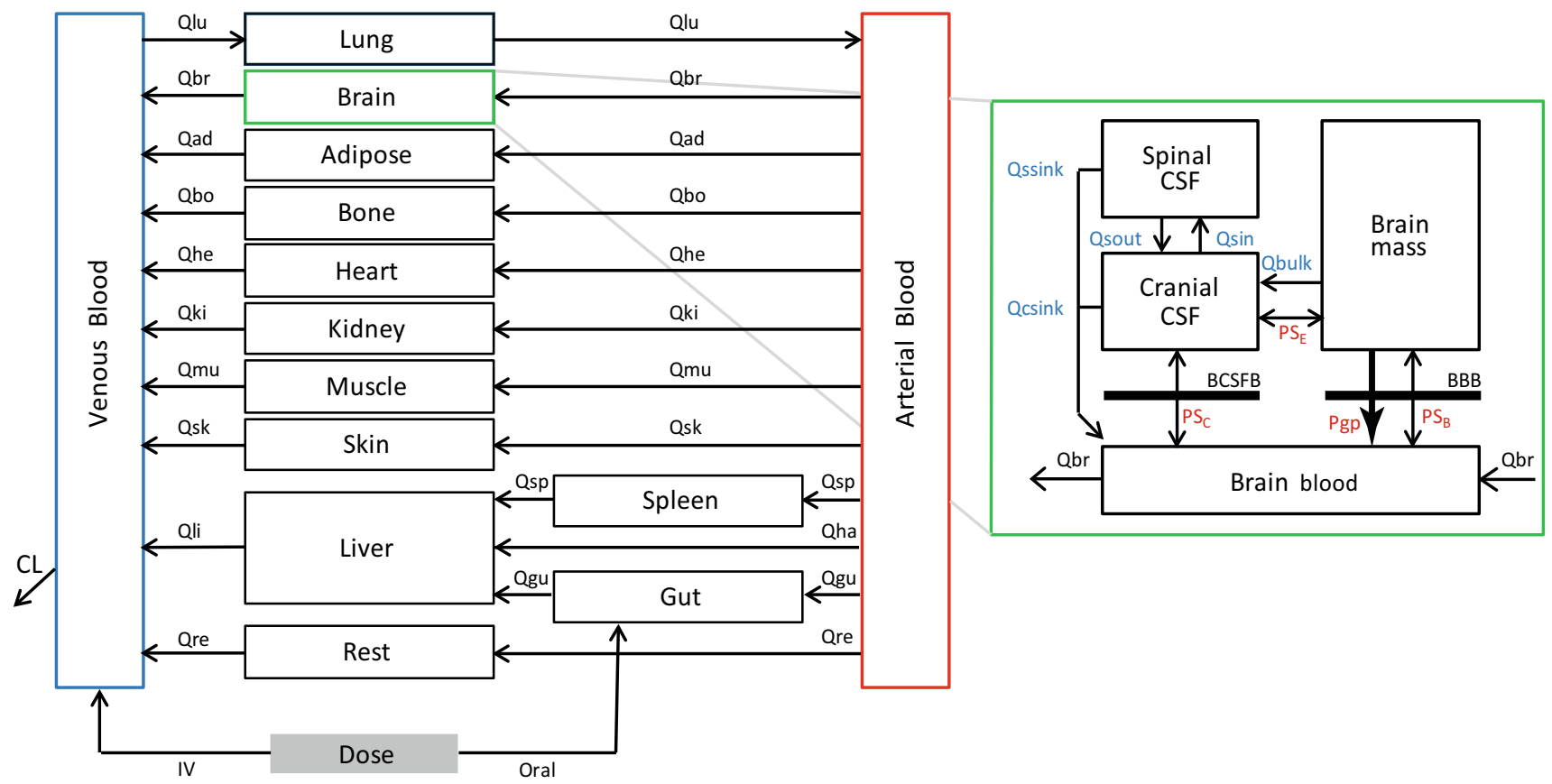

Fig. 1 Schematic outline of the PBPK model including four brain compartments (adapted from Verscheijden et al. (Verscheijden et al. 2019)). Qsin and Qsout represent CSF shuttle flow between cranial CSF and spinal CSF compartments. Qssink and Qcsink are the flows from CSF compartments to blood. Qbulk represents bulk flow from brain mass to cranial CSF. $\mathrm{PS}_{\mathrm{B}}, \mathrm{PS}_{\mathrm{C}}$ and $\mathrm{PS}_{\mathrm{E}}$ represent permeability surface area products between brain blood and brain mass, brain

product was calculated using apparent permeability (Papp) values from in vitro assays in MDCK or Caco- 2 cell lines, as follows ( $\mathrm{Li}$ et al. 2017):

$P S b b b=$ Papp, invitro $\times B B B$ surface area

where PSbbb is the permeability surface area product of the BBB. Papp, in vitro is the Papp in $\mathrm{dm} / \mathrm{h}$ and BBB surface area is the surface area of the blood-brain barrier in $\mathrm{dm}^{2}$. Multiple Papp values were averaged, if available. Binding of drugs to brain components was reflected by the unbound fraction in brain mass (fubm) derived from animal experiments, which show good correlation with human values, or in silico predicted fractions (Online Resource 1). Only unbound drug is assumed to cross the brain barriers (Verscheijden et al. 2019).

\section{Parameters for Pgp substrates with in vitro transport data: digoxin, quinidine and verapamil}

For Pgp substrates digoxin, verapamil, quinidine (Bauer et al. 2012; Kusuhara et al. 1997; Mayer et al. 1997; Pussard et al. 2007; Römermann et al. 2013; Sadiq et al. 2015; Schinkel et al. 1995), in vitro Caco-2 maximum rate blood and cranial CSF, and brain mass and cranial CSF, respectively. Pgp represents active BBB Pgp-mediated transport. Subscripts lu, br, ad, bo, he, ki, mu, sk, li, re, gu, sp, ha denote lung, brain, adipose tissue, bone, heart, kidney, muscle, skin, liver, rest tissue, gut, spleen and hepatic artery, respectively. CL is the total clearance from the model. IV and oral indicate intravenous and oral route of administration

of transport (Vmax) and affinity constant $(\mathrm{Km})$ parameters were extracted from literature, in addition to passive permeability (Papp) and brain binding (fubm) parameters (Online Resource 1). Digoxin and verapamil efflux parameters have been incorporated previously in liver and intestinal PBPK model compartments (Neuhoff et al. 2013a, b). Vmax values were corrected for differences in Pgp protein abundance between the in vitro cell system and in vivo blood-brain barrier micro-vessels and scaled to an in vivo parameter using the equation:

$V_{\max b b b}=V_{\max , \text { vitro }} / \operatorname{Pr}$ ocell $* \frac{\text { Pgp abundance }(M v)}{\text { Pgp abundance }(\text { Caco2 })} * B M v P G B * B W$

where Vmaxbbb is the maximum rate of transport in the total $\mathrm{BBB}$ in $\mathrm{pmol} / \mathrm{min}$ and Vmax,vitro is the maximum rate of transport in Caco-2 cells in pmol $/ \mathrm{min} / \mathrm{cm} 2$. Procell is the amount of protein in the in vitro system, which was assumed to be $150 \mathrm{ug} / \mathrm{cm} 2$. Pgp abundance(Caco2) represents the Pgp protein abundance in the intestinal-derived Caco- 2 cell-line and Pgp abundance(Mv) the Pgp protein abundance in the endothelial BBB microvessels, which was reportedly on average 0.9 and $4.21 \mathrm{pmol} / \mathrm{mg}$ total protein, respectively (Al-Majdoub et al. 2019; Brück et al. 2017; Shawahna et al. 
2011; Uchida et al. 2011). BMvPGB, the amount of brain micro-vessel per gram of brain, was reported to be $244 \mathrm{ug}$ protein/g brain, and the value used for BW (brain weight) was age-dependent (as reported previously (Verscheijden et al. 2019)), and assumed to be $1400 \mathrm{~g}$ in adults ( $\mathrm{Li}$ et al. 2017).

Pgp-mediated transport was incorporated in time-based differential equations describing the rate of change in brain and blood drug concentration according to the following Michaelis Menten equation:

$\frac{d A, \text { active }}{d t}=\frac{f \exp * V \max , b b b * f u b m * C b m}{K m+f u b m * C b m}$

where fubm is the fraction of unbound drug in brain mass and $\mathrm{Cbm}$ the total concentration of drug in brain mass. Active efflux transport results in a reduction in the amount of drug present in the brain compartment, while it will increase the amount of drug in the blood compartment over time (dA,active/dt). For simulations in the paediatric population, Vmax was multiplied with the relative Pgp expression (fexp $=0.57)$ compared to adult expression reported by Lam et al. (Lam et al. 2015).

\section{Parameters for Pgp substrates without in vitro transport data: ivermectin, indinavir, vincristine, docetaxel, paclitaxel, olanzapine and citalopram}

Simulations were also performed for Pgp substrates for which no in vitro transporter activity was available (Bundgaard et al. 2012; Chu et al. 2012; Gallo et al. 2003; Geyer et al. 2009; Kemper et al. 2003; Kiki-Mvouaka et al. 2010; Kim et al. 1998; Schinkel et al. 1994; Uhr and Grauer 2003; Wang et al. 2010, 2004). In these models, Pgp activity was optimized to predict measured CSF data (reported in "Model verification and parameter optimization using published clinical studies" below) using the equation:

$\frac{d A, \text { active }}{d t}=C L p g p * f u b m * C b m$

where CLpgp is the (optimized) BBB-mediated Pgp efflux clearance in $\mathrm{L} / \mathrm{h}$, fubm is the unbound fraction of drug in brain, and $\mathrm{Cbm}$ is the total brain drug concentration. The optimized Pgp clearance parameters and other drug-related parameters are reported in Online Resource 1.

\section{Model verification and parameter optimization using published clinical studies}

For model verification (digoxin, verapamil and quinidine) and optimization of Pgp efflux clearance (ivermectin, indinavir, vincristine, docetaxel, paclitaxel, olanzapine, and citalopram), clinical studies with relevant plasma and CSF drug concentrations were used. Studies included patients suffering from a wide variety of conditions or receiving comedication, which potentially could have affected drug brain disposition. A summary of all clinical studies and their characteristics is reported in Table 1. Only for digoxin, a study in children was used.

Simulations were performed using a virtual population of 100 individuals, who were matched with the original clinical study for dosing regimen, age range and fraction female/male, if reported. Simulated median, 5th percentile, 95th percentile, minimum and maximum concentration-time profiles were compared with observed values from clinical studies. In addition, plasma and CSF prediction errors were calculated as performed previously according to the equation (Yamamoto et al. 2017):

$P E=\frac{\text { Yobs, } i-\text { Ypred, } \text { median }, i}{(\text { Yobs }, i+\text { Ypred }, \text { median }, i) / 2}$

where Yobs,i is the ith individual or mean observation in the clinical study at a specific point in time and Ypred,median,i is the median concentration predicted at the same point in time. Variability in the clinically measured PK values is assumed to cancel out in the analysis. Therefore, median PE ideally equals 0 . A median PE of \pm 0.667 and \pm 1 refer to a twofold or a threefold median difference between predicted and observed values, respectively.

\section{Assessment of species-specific Pgp activity}

Human adult and pediatric simulations were performed with and without Pgp-mediated active transport. Effects of Pgp on brain mass area under the curve (AUC) and plasma AUC were quantified for one dosing interval when the system was at steady state using the (prolonged) dosing regimen described in the clinical studies (Table 1). Clinical studies with vincristine and docetaxel only reported single dose PK data; therefore, dosing was repeated weekly for vincristine or once every three weeks for docetaxel. Total brain-to-plasma AUC ratios (Kp,brain), in the situation where Pgp was not active, were divided by the Kp,brain in case Pgp was considered (i.e. Equations 3 or 4 included in the PBPK model) for adults and children, using the formula:

Kpratio $=\frac{\text { Kpbrain, } \text { Pgpinhbited }}{\text { Kpbrain, } \text { Pgpactive }}$

The same equation was used to calculate $\mathrm{Kp}$ ratios in adult rodent studies for Pgp substrates listed above, where AUC values or single-point drug concentrations in plasma and brain were used to calculate $\mathrm{Kp}$,brain. $\mathrm{Kp}$,brain values in knockout rodents or rodents in which Pgp was inhibited were divided by $\mathrm{Kp}$,brain obtained from wildtype, untreated animals (Bauer et al. 2012; Bundgaard et al. 2012; Chu et al. 
Table 1 Characteristics of studies used for model verification and parameter optimization

\begin{tabular}{|c|c|c|c|c|c|c|}
\hline Drug & Number of patients & Dose & Co-medication & Age & Indication & $\begin{array}{l}\text { CSF PK sample } \\
\text { collection }\end{array}$ \\
\hline \multicolumn{7}{|c|}{ No transporter substrates } \\
\hline $\begin{array}{l}\text { Quetiapine } \\
\text { (Nikisch et al. } \\
\text { 2010) }\end{array}$ & 22 & $600 \mathrm{mg} /$ day oral & - & $18-55$ y & $\begin{array}{l}\text { Schizophrenic } \\
\text { episode }\end{array}$ & Lumbar puncture \\
\hline $\begin{array}{l}\text { Oxycodone } \\
\text { (Kokki et al. } \\
\text { 2014) }\end{array}$ & 11 & $0.092 \mathrm{mg} / \mathrm{kg} \mathrm{IV}$ & $\begin{array}{l}\text { Diazepam, paracet- } \\
\text { amol, midazolam, } \\
\text { propofol, remifen- } \\
\text { tanil, rocuronium, } \\
\text { sevoflurane }\end{array}$ & $26-60 y$ & $\begin{array}{l}\text { Postoperative epi- } \\
\text { dural analgesia }\end{array}$ & Epidural catheter \\
\hline $\begin{array}{l}\text { Mirtazapine } \\
\text { (Paulzen et al. } \\
\text { 2015) }\end{array}$ & 16 & $33.3 \mathrm{mg} /$ day oral & $\begin{array}{l}\text { Quetiapine, venla- } \\
\text { faxine, citalopram }\end{array}$ & $28-78$ y & $\begin{array}{l}\text { Major depressive } \\
\text { episode }\end{array}$ & Lumbar puncture \\
\hline $\begin{array}{l}\text { Etoricoxib } \\
\text { (Piirainen et al. } \\
\text { 2016) }\end{array}$ & 12 & $60 \mathrm{mg}$ oral & $\begin{array}{l}\text { Paracetamol, } \\
\text { levobupivacaine, } \\
\text { fentanyl, oxyco- } \\
\text { done }\end{array}$ & $56-72$ y & $\begin{array}{l}\text { Total hip arthro- } \\
\text { plasty }\end{array}$ & Spinal catheter \\
\hline $\begin{array}{l}\text { Dexketoprofen } \\
\text { (Piirainen et al. } \\
\text { 2016) }\end{array}$ & 12 & $0.5 \mathrm{mg} / \mathrm{kg} \mathrm{IV}$ & $\begin{array}{l}\text { Paracetamol, } \\
\text { levobupivacaine, } \\
\text { fentanyl, oxyco- } \\
\text { done }\end{array}$ & $53-71$ y & $\begin{array}{l}\text { Total hip arthro- } \\
\text { plasty }\end{array}$ & Spinal catheter \\
\hline $\begin{array}{l}\text { Lacosamide (May } \\
\text { et al. 2015) }\end{array}$ & 21 & $166 \mathrm{mg} / 12 \mathrm{~h}$ oral & $\begin{array}{l}\text { Various anti-epilep- } \\
\text { tic drugs }\end{array}$ & $18-65$ y & Epilepsy & Lumbar puncture \\
\hline $\begin{array}{l}\text { Ibuprofen (Bra- } \\
\text { zier et al. 2017) }\end{array}$ & 26 & 10 or $20 \mathrm{mg}$ oral & Cromolyn & $55-75$ y & Healthy volunteers & Lumbar puncture \\
\hline \multicolumn{7}{|l|}{ Pgp substrates } \\
\hline $\begin{array}{l}\text { Digoxin (Allonen } \\
\text { et al. 1977) }\end{array}$ & $\begin{array}{l}11 \text { adults } \\
8 \text { infants }\end{array}$ & $\begin{array}{l}0.0032 \mathrm{mg} / \mathrm{kg} / \mathrm{day} \\
\text { oral (adult) } \\
0.011 \mathrm{mg} / \mathrm{kg} / \text { day } \\
\text { oral (infant) }\end{array}$ & Not available & $\begin{array}{l}\text { 68-92 y (adult) } \\
25-81 \text { d (infant) }\end{array}$ & $\begin{array}{l}\text { Disease not speci- } \\
\text { fied (adult) } \\
\text { Hearth failure/ } \\
\text { hydrocephalus } \\
\text { (infants) }\end{array}$ & Lumbar puncture \\
\hline $\begin{array}{l}\text { Verapamil } \\
\text { (Narang et al. } \\
\text { 1988) }\end{array}$ & 7 & $480 \mathrm{mg} /$ day oral & - & $22-44 y$ & Schizophrenia & Lumbar puncture \\
\hline $\begin{array}{l}\text { Quinidine (Ochs } \\
\text { et al. 1980) }\end{array}$ & 8 & $385 \mathrm{mg} / 12 \mathrm{~h}$ oral & Not available & $23-70 y$ & $\begin{array}{l}\text { Volunteers sched- } \\
\text { uled for lumbar } \\
\text { puncture }\end{array}$ & Lumbar puncture \\
\hline $\begin{array}{l}\text { Ivermectin (Rose } \\
\text { et al. 2009) }\end{array}$ & 1 & $30 \mathrm{~g} /$ day oral & $\begin{array}{l}\text { Broad spectrum } \\
\text { antibiotics }\end{array}$ & $59 \mathrm{y}$ & $\begin{array}{l}\text { Lymphocytic } \\
\text { leukaemia, Stron- } \\
\text { gyloides } \\
\text { stercoralis infection }\end{array}$ & Lumbar puncture \\
\hline $\begin{array}{l}\text { Indinavir (Haas } \\
\text { et al. 2000) }\end{array}$ & 8 & $800 \mathrm{mg} / 8 \mathrm{~h}$ oral & $\begin{array}{l}\text { Zidovudine, lami- } \\
\text { vudine, stavudine }\end{array}$ & $31-50 y$ & HIV infection & $\begin{array}{l}\text { Lumbar intrathecal } \\
\text { catheter }\end{array}$ \\
\hline $\begin{array}{c}\text { Vincristine (Jack- } \\
\text { son et al. 1981) }\end{array}$ & 2 & $2 \mathrm{mg}$ IV & Methotrexate & $60-66$ y & $\begin{array}{l}\text { Non-Hodgkin's } \\
\text { lymphoma or } \\
\text { leukaemia }\end{array}$ & Ventricular catheter \\
\hline $\begin{array}{l}\text { Docetaxel (ten } \\
\text { Tije et al. 2004) }\end{array}$ & 1 & $75 \mathrm{mg} / \mathrm{m} 2 \mathrm{IV}$ & Not available & Not available & $\begin{array}{l}\text { Metastatic breast } \\
\text { cancer }\end{array}$ & Lumbar puncture \\
\hline $\begin{array}{l}\text { Paclitaxel (Chen } \\
\text { et al. 2006) }\end{array}$ & 6 & $175 \mathrm{mg} / \mathrm{m} 2 \mathrm{IV}$ & $\begin{array}{l}\text { Dexamethasone, } \\
\text { phenytoin }\end{array}$ & $34-73$ y & $\begin{array}{l}\text { Original brain } \\
\text { tumour or brain } \\
\text { metastases }\end{array}$ & $\begin{array}{l}\text { Ommaya reser- } \\
\text { voirs or lumbar } \\
\text { puncture }\end{array}$ \\
\hline $\begin{array}{l}\text { Olanzapine } \\
\text { (Skogh et al. } \\
\text { 2011) }\end{array}$ & 29 & $11.6 \mathrm{mg} /$ day oral & $\begin{array}{l}\text { Benzodiazepines, } \\
\text { zopiclone }\end{array}$ & $23-50 y$ & $\begin{array}{l}\text { Schizophrenia or } \\
\text { schizoaffective } \\
\text { disorder }\end{array}$ & Lumbar puncture \\
\hline $\begin{array}{l}\text { Citalopram } \\
\text { (Paulzen et al. } \\
\text { 2016) }\end{array}$ & 18 & $21.1 \mathrm{mg} /$ day oral & - & $28-84$ y & $\begin{array}{l}\text { Different psychiat- } \\
\text { ric diagnoses }\end{array}$ & Lumbar puncture \\
\hline
\end{tabular}


2012; Gallo et al. 2003; Geyer et al. 2009; Kemper et al. 2003; Kiki-Mvouaka et al. 2010; Kim et al. 1998; Kusuhara et al. 1997; Mayer et al. 1997; Pussard et al. 2007; Römermann et al. 2013; Sadiq et al. 2015; Schinkel et al. 1994, 1995; Uhr and Grauer 2003; Wang et al. 2010, 2004). Human and rodent $\mathrm{Kp}$ ratios were compared and considered different when ratios exceeded an arbitrary value of twofold difference.

\section{Results}

\section{Substrates entering the brain by passive diffusion}

The model was first verified with quetiapine, oxycodone, mirtazapine, etoricoxib, dexketoprofen, lacosamide and ibuprofen for which BBB passage is only subject to passive diffusion. Reasonable predictions could be made for most compounds, although the dexketoprofen CSF concentration-time profile was overestimated with a prediction error of -0.81 . Overlays of predicted and measured data are shown in Fig. 2 together with calculated prediction errors.

\section{Pgp substrates with in vitro transport data}

Pgp transport parameters were included in the model for digoxin, quinidine and verapamil. To optimally capture clinically measured digoxin CSF values, the Pgp protein abundance ratio between Caco-2 and brain micro-vessels in Eq. 2 had to be multiplied with 9. The adjusted value was kept the same for the paediatric digoxin, verapamil and quinidine simulations. Simulated digoxin plasma and CSF PK profiles with and without active Pgp transport are shown in Fig. 3. Inclusion of active Pgp transport resulted in an improved overlay between simulated and measured concentrations in CSF in adults and children between 25 and 81 days postnatal age, as shown by the plots and measured median prediction errors (Fig. 3). In addition, adding Pgp activity to the model resulted in a better agreement between simulated and measured verapamil and quinidine CSF drug concentrations with median prediction errors more closely to 0 (Fig. 4).

\section{Pgp substrates without in vitro transport data}

Model simulations were also performed for the Pgp substrate drugs ivermectin, indinavir, vincristine, docetaxel, paclitaxel, olanzapine and citalopram. Pgp activity was quantified by optimization of the CLpgp parameter in the model with CSF measurements, although this parameter was not needed to obtain an overlay with measured data for paclitaxel and citalopram (Fig. 5). The predicted and observed data did correspond well for all drugs after CLpgp optimization, except for docetaxel, as a relatively constant measured CSF concentration did not match with the simulated profile. A reduction of the BBB and BCSFB passive permeability product improved the model-based prediction for this drug (Fig. 5). Including Pgp activity had little influence on the simulated plasma concentration-time curves for all compounds investigated, with steady-state concentrations being $<1 \%$ different from the situation where BBB Pgp was not considered (data not shown).

\section{Assessment of species-specific Pgp activity}

Plasma concentration-corrected brain concentrations (Kp,brain values) were calculated with and without Pgp activity and $\mathrm{Kp}$ ratios ranged from 1.0 to 45 (Table 2). Docetaxel was not considered due to the initial mismatch between predicted and observed values. Data reported in rodent knockout and inhibition studies were included, to evaluate the difference with human predicted values (Table 2). Human model-based predictions for digoxin, verapamil, indinavir, paclitaxel and citalopram resulted in $\geq$ twofold lower Kp ratios compared to rodent studies. In contrast, the Kp ratio of vincristine was $\geq$ twofold higher in the human model simulation compared to the values found in rodents (Table 2).

\section{Discussion}

Transport across the blood-brain barrier was modelled for drugs that enter the brain via passive diffusion only and for typical P-gp drug substrates. Incorporation of active transport in the model improved the prediction of human adult and paediatric CSF drug concentrations for Pgp substrates, although this was not necessary for drugs entering brain via passive diffusion (Figs. 3, 4 and 5). The effect of Pgp activity on brain drug exposure tended to be lower according to the human simulation as compared to mouse and rat Pgpknockout/-inhibition studies (Table 2).

Interspecies variability in the influence of Pgp on brain drug concentrations can be explained by differences in transporter expression, as well as transporter activity. Compared to human, Pgp expression in mouse is 2.3-fold higher and in rat about fourfold higher (Al Feteisi et al. 2018; Uchida et al. 2011). In vitro studies also point towards a variable activity and different substrate affinity of human Pgp compared with the mouse orthologue. However, this needs further investigation, as variable transporter activity between species has not been normalized for expression differences in the in vitro experimental systems (Schinkel et al. 1995; Xia et al. 2006; Yamazaki et al. 2001).

The verapamil model simulations reported in this study are in line with clinical human ${ }^{11} \mathrm{C}$-verapamil PET studies, where (near) complete inhibition of Pgp by tariquidar 

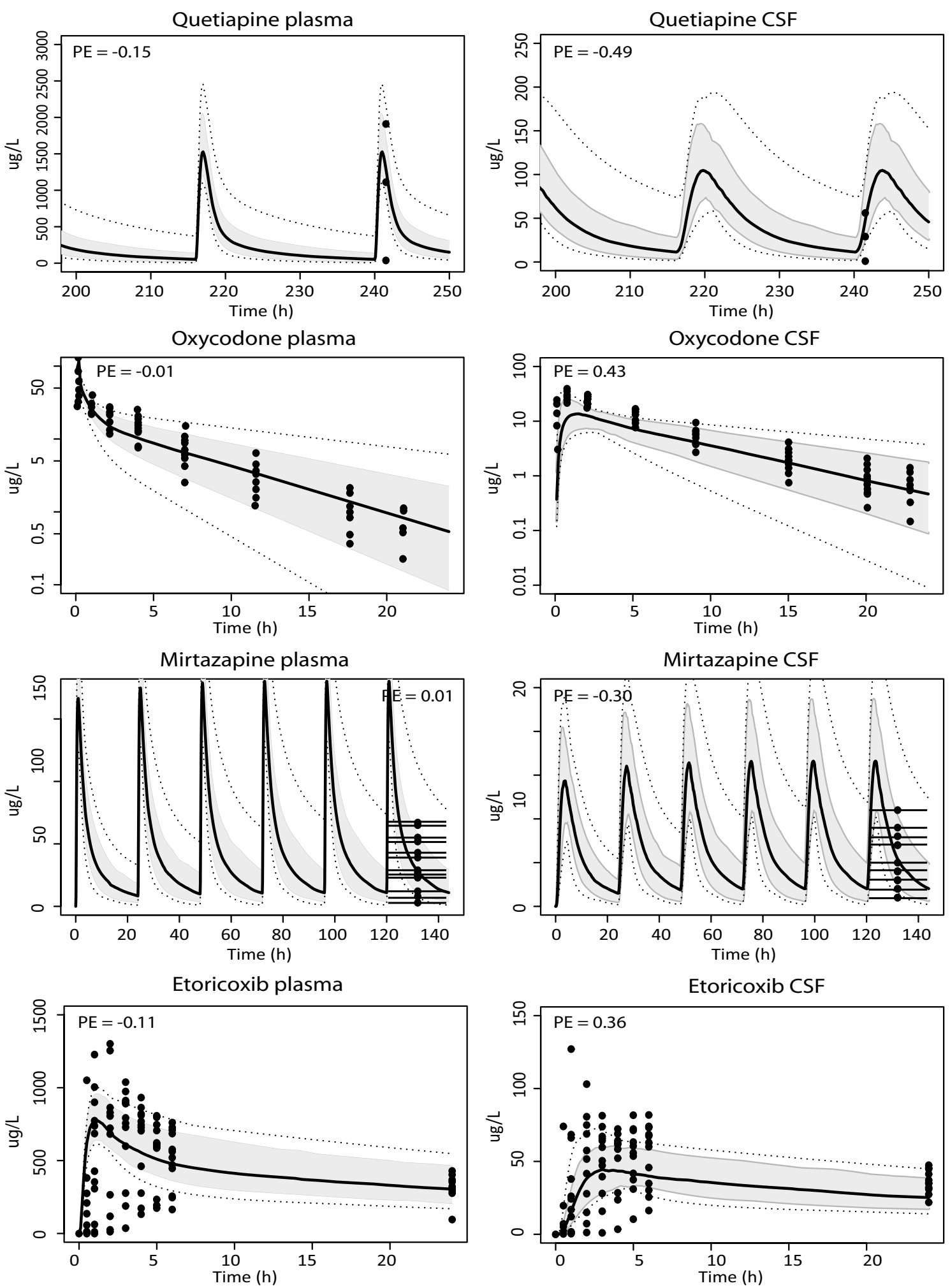

Fig. 2 Model simulations for drugs reaching the brain via passive diffusion only. Simulations in plasma and CSF for the compounds quetiapine $(600 \mathrm{mg} /$ day, oral $)$, oxycodone $(0.092 \mathrm{mg} / \mathrm{kg}$, IV), mirtazapine (33.3 mg/day, oral), etoricoxib (60 mg, oral), dexketoprofen $(0.5 \mathrm{mg} /$ $\mathrm{kg}$, IV), lacosamide (166 mg/12 h, oral), and ibuprofen (10 mg, oral). The black solid line indicates the median simulated value. The grey

area represents $90 \% \mathrm{CI}$ in inter-individual variability. Dotted lines indicate minimum and maximum simulated values. Dots are individual or mean observed values. Horizontal lines indicate the range in which measured samples were obtained. Prediction errors where calculated as described in the "Methods" section, $\mathrm{PE}=\frac{\text { Yobs,i-Ypred,median, } \mathrm{i}}{(\text { Yobs, }, \mathrm{i}+\text { Ypred,median,i }) / 2}$ 

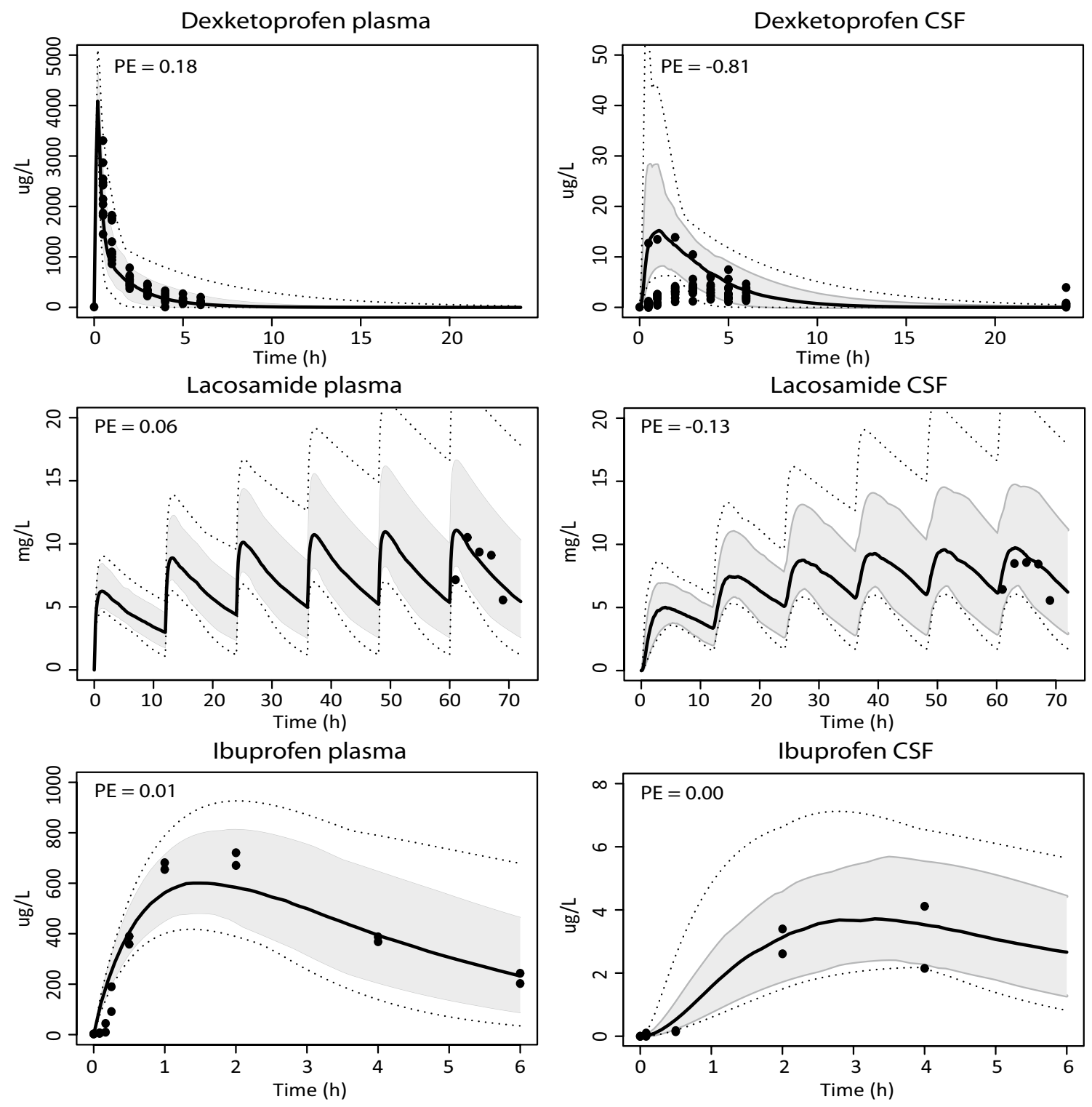

Fig. 2 (continued)

was achieved. Brain disposition increased by $273 \%$, which is close to the $\sim 2.3$-fold difference predicted here, but far below the up to $10 \times$ higher $\mathrm{Kp}$ ratios reported in rats and mice, which is can be explained by differences in expression or transporter affinity (Table 2) (Bauer et al. 2015; Zolnerciks et al. 2011). This is also in line with higher brain-to-plasma $\mathrm{Kp}$ values reported in rat compared to human and monkey for the Pgp substrates ${ }^{11} \mathrm{C}$ GR205171 and ${ }^{18} \mathrm{~F}$-altanserin, even when corrected for differences in plasma protein binding and clearance (Syvänen et al. 2009). Therefore, species differences in transporter activity tend towards a lower Pgp activity in human BBB in accordance with our results, however, this can be substrate dependent as shown for vincristine (Syvänen et al. 2009).

Differences in brain exposure between animals and humans could have consequences for toxicity testing and drug development. Although species differences are often considered in toxicity testing by taking into account an interspecies safety factor of 10 , of which a factor 4 is used specifically for inter-species differences in toxicokinetics, differences in blood-brain barrier drug disposition already can outrange this value when evaluating Pgp transporter substrates (Dankovic et al. 2015). Pgp activity has also been a topic of interest in drug development for CNS diseases, as substrates are less likely to reach the target site (Mahar Doan et al. 2002). The findings in this study indicate that 
Digoxin plasma adult

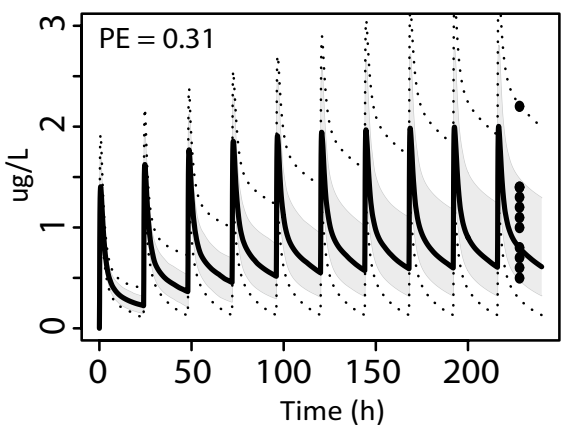

Digoxin plasma pediatric

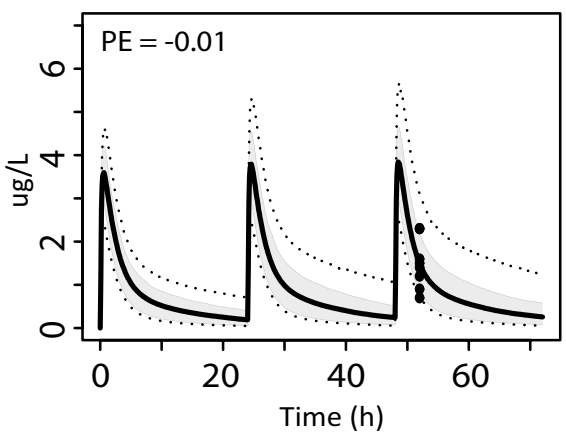

Digoxin CSF adult - Pgp

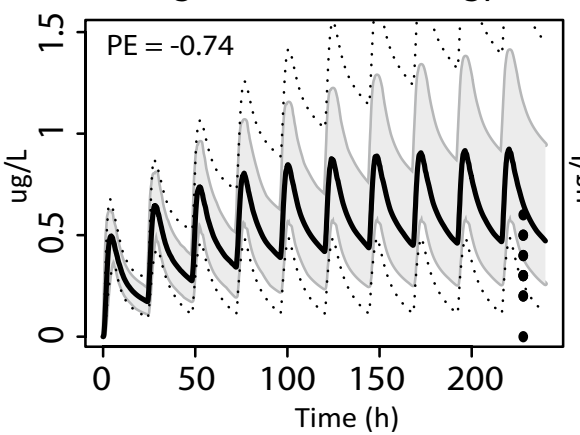

Digoxin CSF pediatric - Pgp

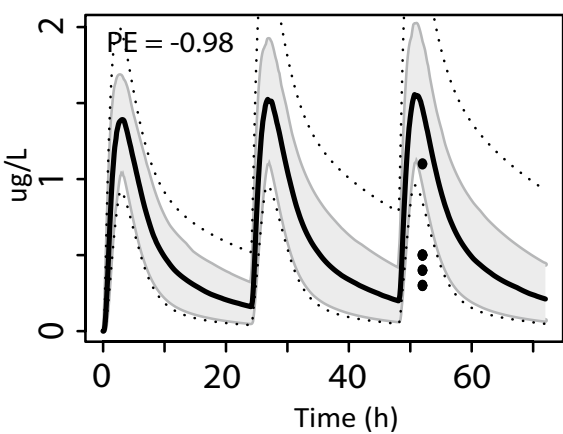

Digoxin CSF adult + Pgp

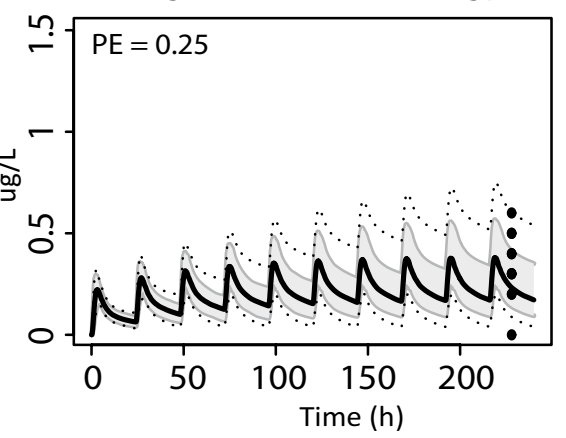

Digoxin CSF pediatric + Pgp

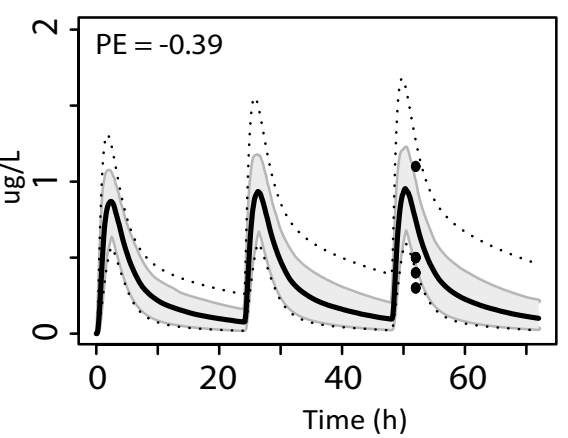

Fig. 3 Predictions of digoxin concentrations in plasma and CSF of adults and young children. Simulations of plasma and CSF (with and without Pgp activity) concentrations in adults $(0.0032 \mathrm{mg} / \mathrm{kg} /$ day digoxin, oral) and young children $(0.011 \mathrm{mg} / \mathrm{kg} /$ day digoxin, oral). The black solid line indicates the median simulated value. The grey area represents $90 \%$ CI in inter-individual variability. Dotted lines indicate minimum and maximum simulated values. Dots are individual observed values. Prediction errors where calculated as described in the "Methods" section, PE $=\frac{\text { Yobs,i-Ypred,median,i }}{(\text { Yobs,i+Ypred,median,i)/2 }}$

proteomic measurements of transporter abundance can be large, which require standardization of procedures (Harwood et al. 2016). In addition, quantitative proteomics would ideally be performed on the same cells used in the in vitro transport experiments to minimize the effect of culture conditions. Currently, verification of model-predicted transporter activity is therefore required. A second limitation is that predicted brain mass exposures could not be validated with measured data, as they were not available for the compounds studied. Drug concentrations in CSF will not be the same as in ECF, but are strongly linked, e.g. due to the flow of drugs from brain mass to the cranial CSF. This means that accurate predictions in the CSF provide indirect information about the accuracy of the simulated drug concentrations in brain. In addition, the human brain model proved suitable for predicting brain parenchyma concentrations in previous studies, as was shown for morphine and AZD1775, but these compounds are less clear BBB Pgp substrates and therefore not used here ( $\mathrm{Li}$ et al. 2017; Verscheijden et al. 2021). Predicted Kp ratios also correlated well with human clinical ${ }^{11} \mathrm{C}$-verapamil PET values, as discussed above (Bauer et al. 2015; Li et al. 2017). Third, Kp values in rodents are not always derived 

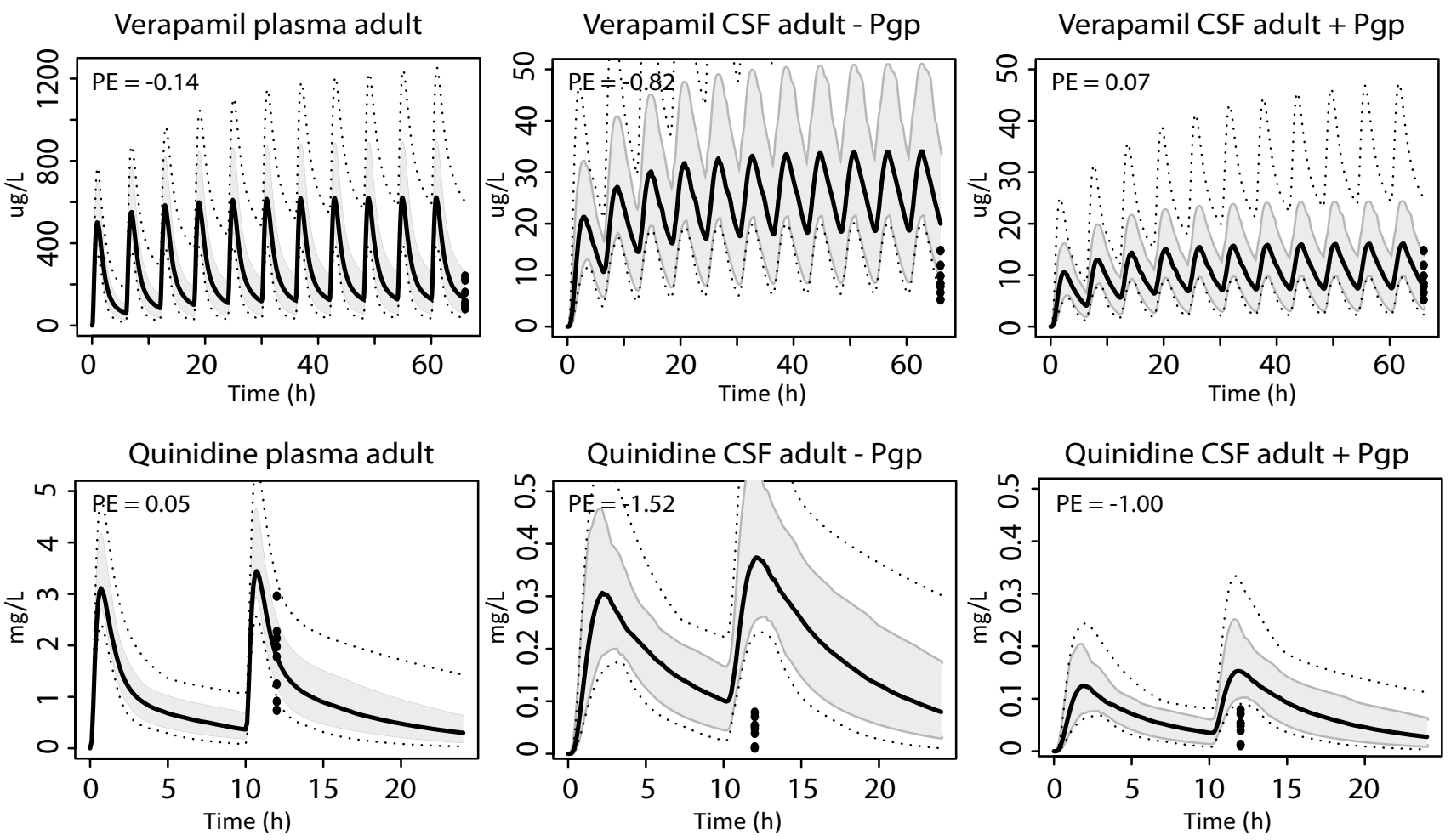

Fig. 4 Predictions of verapamil and quinidine concentrations in plasma and CSF of adults. Simulations in plasma and CSF (with and without Pgp activity) after oral doses of $480 \mathrm{mg} /$ day verapamil and $385 \mathrm{mg} / 12 \mathrm{~h}$ quinidine. The black solid line indicates the median simulated value. The grey area represents $90 \% \mathrm{CI}$ in inter-individual varia-

at plasma concentrations comparable to the human clinical studies. This is the case for olanzapine and indinavir, where plasma concentrations in rat where about tenfold higher and fivefold lower than in human plasma, respectively. Drug plasma concentrations are substantially below Km values for olanzapine, but around $\mathrm{Km}$ for indinavir, which might result in saturation of transporters (Boulton et al. 2002; Lee et al. 1998). For the other Pgp substrates, Kp values were determined at similar plasma concentrations in humans and rodents. Last, whereas all transporter substrates considered are transported by Pgp, other efflux transporters might contribute. This could result in an overestimation of the predicted Pgp effect in human as compared to mouse Pgp knockout and inhibition studies. The observed trend indicating more Pgp activity in rodents compared to human studies would in this case be even more pronounced. Uptake transporter activity potentially differs between species and could become important when compounds would be substrates such as paclitaxel which is described to be a substrate for hepatic OATP2B1 (Tanino et al. 2009). However, species differences in uptake transporter activity are unknown and for most Pgp substrates reported here, no BBB uptake transporter activity has been described. bility. Dotted lines indicate minimum and maximum simulated values. Dots are individual observed values. Prediction errors where calculated as described in the "Methods" section, $\mathrm{PE}=\frac{\text { Yobs,i-Ypred,median,i }}{(\text { Yobs,i+Ypred,median,i)/2 }}$

The simulations in this study indicate that a PBPK modelbased approach can be used to quantify human adult CSF drug concentrations without clinical data, but only in case when robust in vitro data and scaling factors would be available. In addition, age-appropriate inclusion of Pgp can result in an improved prediction in CSF in children. BBB transport in PBPK models has often been scaled using clinically measured PK data in case no in vitro transport data were available (Gaohua et al. 2016; Li et al. 2017). The advantage of including kinetic parameters determined in vitro is, however, that model predictions are not necessarily dependent on clinically measured data, which could be a valuable strategy in the future in case no brain ECF or CSF samples are available.

In conclusion, a PBPK model was developed to predict human brain disposition for various Pgp substrates. Model simulations were verified with measurements in cerebrospinal fluid. The influence of BBB Pgp activity appeared generally more pronounced in knockout mice and rats compared to the human PBPK model. This indicates that assessment of the central nervous system activity of Pgp substrates in rodents might result in an underestimation of their human efficacy and toxicity. 

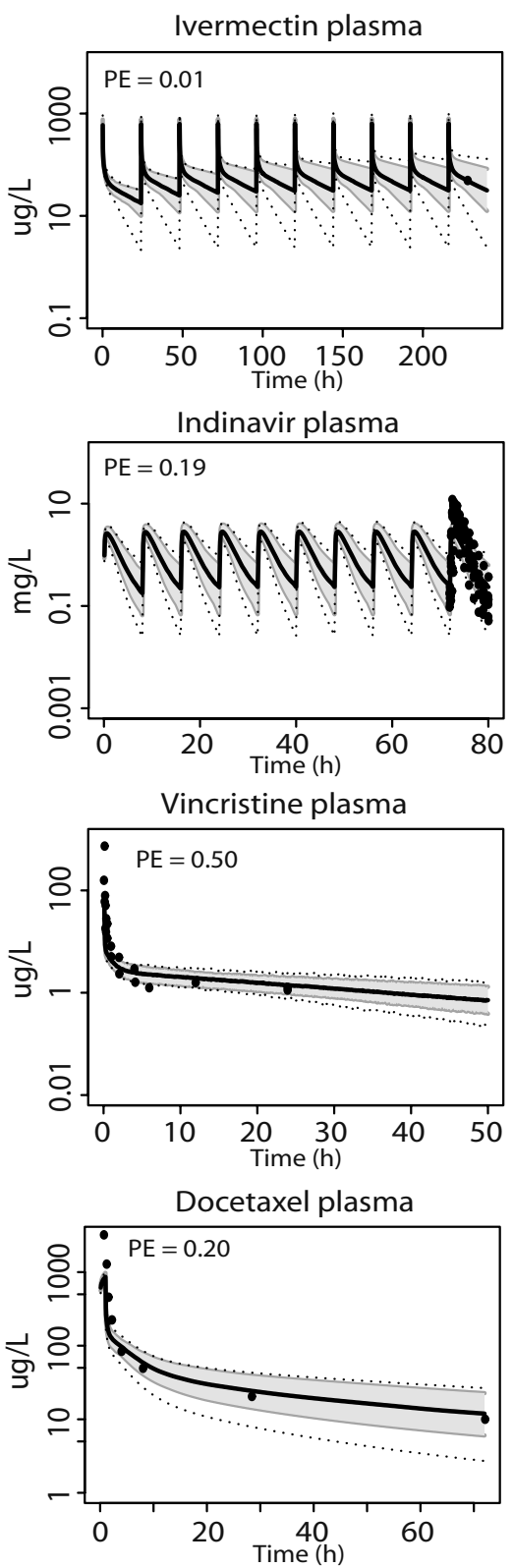

Paclitaxel plasma

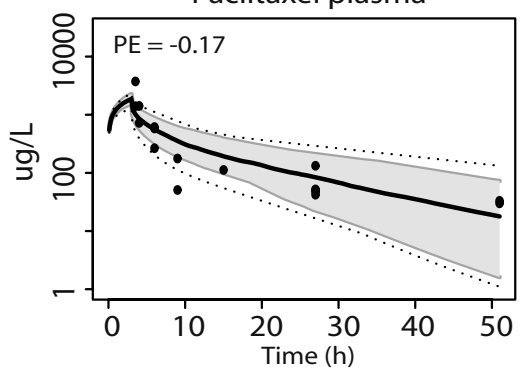

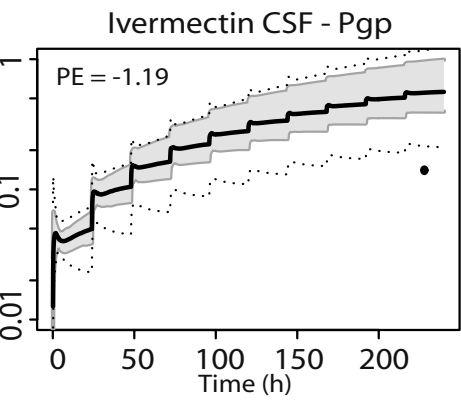
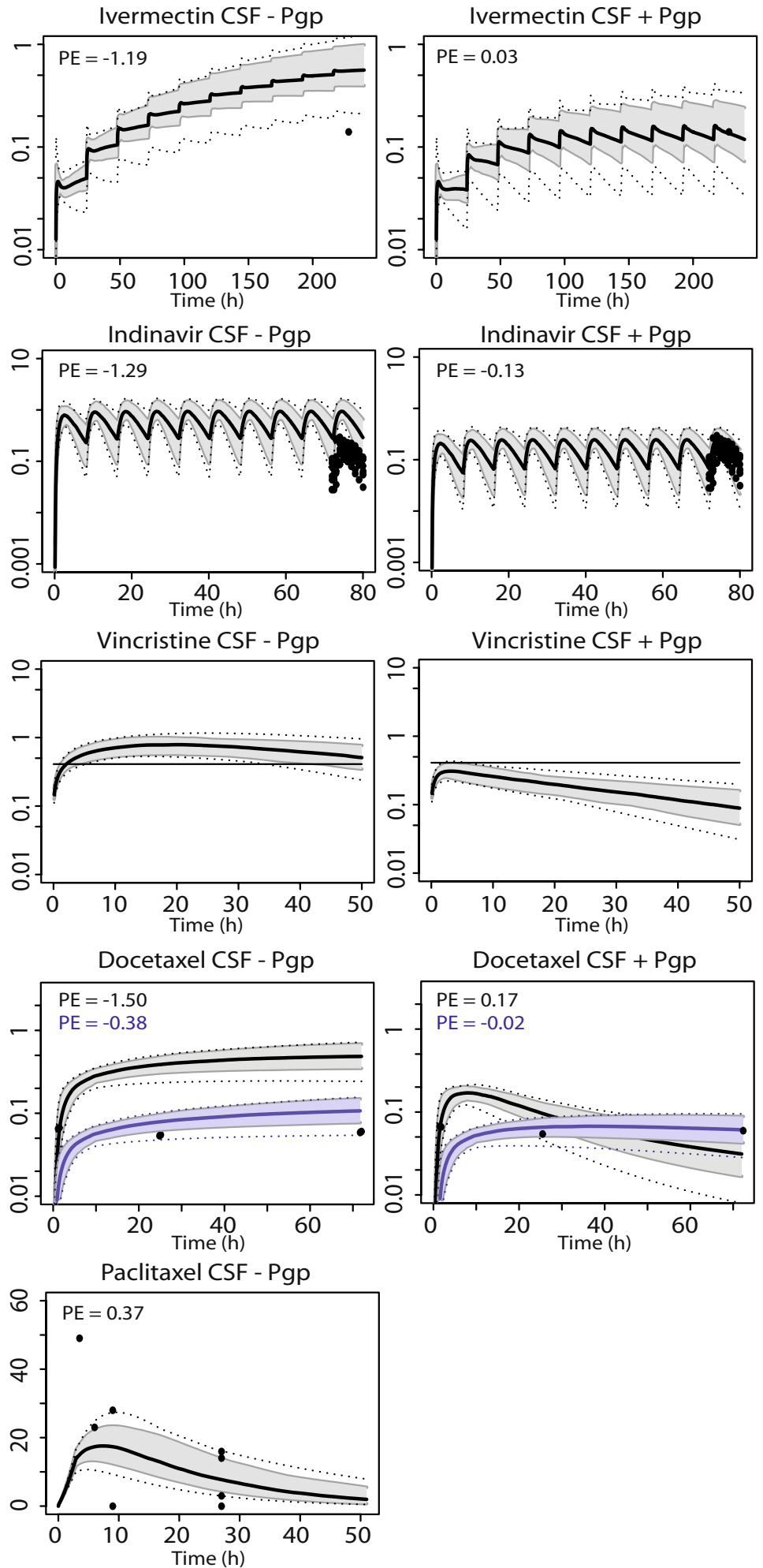

Fig. 5 Model simulations for seven additional Pgp substrates Simulations in plasma and CSF (with and without Pgp activity) for the compounds ivermectin (30 g/day, oral), indinavir $(800 \mathrm{mg} / 8 \mathrm{~h}$, oral), vincristine (2 mg, IV), docetaxel $(75 \mathrm{mg} / \mathrm{m} 2, \mathrm{IV})$, paclitaxel $(175 \mathrm{mg} /$ $\mathrm{m} 2, \mathrm{IV})$, olanzapine (11.6 mg/day, oral), and citalopram $(21.1 \mathrm{mg} /$ day, oral). The black solid line indicates the median simulated value. The grey area represents $90 \% \mathrm{CI}$ in inter-individual variability. Dotted lines indicate minimum and maximum simulated values. Dots are individual observed values. The horizontal line indicates the vincristine lower limit of quantification. Blue lines indicate docetaxel simulations using $20 \%$ and $12.5 \%$ of original passive permeability (PSbb) and BBB Pgp activity (CLpgp) parameter values, respectively. Prediction errors where calculated as described in the "Methods" section, $\mathrm{PE}=\frac{\text { Yobs,i-Ypred,median, } \mathrm{i}}{(\text { Yobs,i+Ypred,median,i)/2 }}$ 

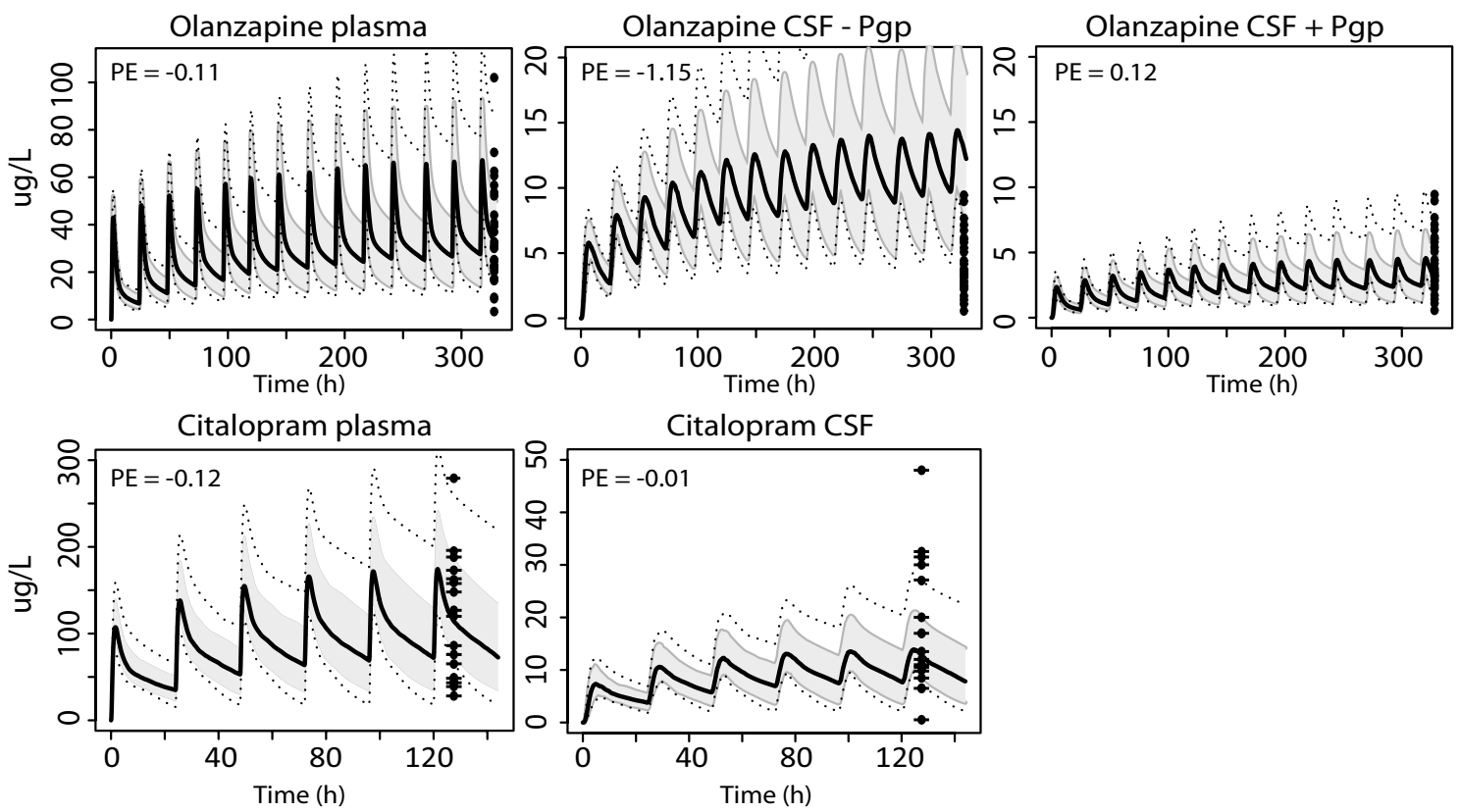

Fig. 5 (continued)

Table $2 \mathrm{Kp}$ ratios in the human brain PBPK model (with and without Pgp) versus Kp ratios from rodent studies (with and without Pgp)

\begin{tabular}{|c|c|c|}
\hline Compound & Kp ratios human PBPK model & $\mathrm{Kp}$ ratios in rat/mouse studies \\
\hline Digoxin (adult 35y) & 2.7 & $\begin{array}{l}\text { 10.0-27.8 } \\
\text { (Mayer et al. 1997; Schinkel et al. 1995) }\end{array}$ \\
\hline Digoxin (child 1mnd) & 2.0 & $\begin{array}{l}\text { 10.0-27.8 } \\
\text { (Mayer et al. 1997; Schinkel et al. 1995) }\end{array}$ \\
\hline Verapamil & 2.3 & $\begin{array}{l}\text { 5.3-30 } \\
\text { (Bauer et al. 2012; Römermann et al. 2013; Sadiq et al. 2015) }\end{array}$ \\
\hline Quinidine & 2.7 & $\begin{array}{l}\text { 4.2-27.6 } \\
\text { (Kusuhara et al. 1997; Pussard et al. 2007) }\end{array}$ \\
\hline Ivermectin & 45 & $\begin{array}{l}\text { 26.4-59.2 } \\
\text { (Geyer et al. 2009; Kiki-Mvouaka et al. 2010; Schinkel et al. 1994) }\end{array}$ \\
\hline Indinavir & 4.5 & $\begin{array}{l}\text { 9.4-21.3 } \\
\text { (Chu et al. 2012; Kim et al. 1998) }\end{array}$ \\
\hline Vincristine & 4.3 & $\begin{array}{l}1.4 \\
\text { (Wang et al. 2010) }\end{array}$ \\
\hline Paclitaxel & 1.0 & $\begin{array}{l}\text { 2.0-7.9 } \\
\text { (Gallo et al. 2003; Kemper et al. 2003) }\end{array}$ \\
\hline Olanzapine & 3.9 & $\begin{array}{l}2.7 \\
\text { (Wang et al. 2004) }\end{array}$ \\
\hline Citalopram & 1.0 & $\begin{array}{l}2.0-3.5 \\
\text { (Bundgaard et al. 2012; Uhr and Grauer 2003) }\end{array}$ \\
\hline
\end{tabular}

Simulations are performed in an "average" adult ( $35 \mathrm{y})$ or pediatric $(1 \mathrm{mnd})$ individual 
Supplementary Information The online version contains supplementary material available at https://doi.org/10.1007/s00204-021-03115-y.

Availability of data and materials All data generated or analyzed during this study are included in this published article, its supplementary information files, and references.

\section{Declarations}

Conflict of interests The authors declare that they have no conflict of interest.

Ethical standards The manuscript does not contain clinical studies or patient data.

Open Access This article is licensed under a Creative Commons Attribution 4.0 International License, which permits use, sharing, adaptation, distribution and reproduction in any medium or format, as long as you give appropriate credit to the original author(s) and the source, provide a link to the Creative Commons licence, and indicate if changes were made. The images or other third party material in this article are included in the article's Creative Commons licence, unless indicated otherwise in a credit line to the material. If material is not included in the article's Creative Commons licence and your intended use is not permitted by statutory regulation or exceeds the permitted use, you will need to obtain permission directly from the copyright holder. To view a copy of this licence, visit http://creativecommons.org/licenses/by/4.0/.

\section{References}

Al Feteisi H, Al-Majdoub ZM, Achour B, Couto N, Rostami-Hodjegan A, Barber J (2018) Identification and quantification of blood-brain barrier transporters in isolated rat brain microvessels. J Neurochem 146(6):670-685. https://doi.org/10.1111/jnc.14446

Allonen H, Anderson KE, Iisalo E, Kanto J, Strömblad LG, Wettrell G (1977) Passage of digoxin into cerebrospinal fluid in man. Acta Pharmacol Toxicol (copenh) 41(3):193-202. https://doi.org/10. 1111/j.1600-0773.1977.tb02139.x

Al-Majdoub ZM, Al Feteisi H, Achour B et al (2019) Proteomic quantification of human blood-brain barrier SLC and ABC transporters in healthy individuals and dementia patients. Mol Pharm 16(3):1220-1233. https://doi.org/10.1021/acs.molpharmaceut. $8 \mathrm{~b} 01189$

Bauer M, Zeitlinger M, Karch R et al (2012) Pgp-mediated interaction between $(\mathrm{R})-[11 \mathrm{C}]$ verapamil and tariquidar at the human bloodbrain barrier: a comparison with rat data. Clin Pharmacol Ther 91(2):227-233. https://doi.org/10.1038/clpt.2011.217

Bauer M, Karch R, Zeitlinger M et al (2015) Approaching complete inhibition of P-glycoprotein at the human blood-brain barrier: an (R)-[11C]verapamil PET study. J Cereb Blood Flow Metab 35(5):743-746. https://doi.org/10.1038/jcbfm.2015.19

Bhatt DK, Mehrotra A, Gaedigk A et al (2019) Age- and genotypedependent variability in the protein abundance and activity of six major uridine diphosphate-glucuronosyltransferases in Human Liver. Clin Pharmacol Ther 105(1):131-141. https://doi.org/10. 1002/cpt.1109

Boström E, Simonsson US, Hammarlund-Udenaes M (2005) Oxycodone pharmacokinetics and pharmacodynamics in the rat in the presence of the P-glycoprotein inhibitor PSC833. J Pharm Sci 94(5):1060-1066. https://doi.org/10.1002/jps.20327
Boulton DW, DeVane CL, Liston HL, Markowitz JS (2002) In vitro P-glycoprotein affinity for atypical and conventional antipsychotics. Life Sci 71(2):163-169. https://doi.org/10.1016/s00243205(02)01680-6

Brazier D, Perry R, Keane J, Barrett K, Elmaleh DR (2017) Pharmacokinetics of cromolyn and ibuprofen in healthy elderly volunteers. Clin Drug Investig 37(11):1025-1034. https://doi.org/10. 1007/s40261-017-0549-5

Brück S, Strohmeier J, Busch D, Drozdzik M, Oswald S (2017) Caco-2 cells - expression, regulation and function of drug transporters compared with human jejunal tissue. Biopharm Drug Dispos 38(2):115-126. https://doi.org/10.1002/bdd.2025

Bundgaard C, Jensen CJ, Garmer M (2012) Species comparison of in vivo P-glycoprotein-mediated brain efflux using mdr1a-deficient rats and mice. Drug Metab Dispos 40(3):461-466. https:// doi.org/10.1124/dmd.111.043083

Chen J, Balmaceda C, Bruce JN et al (2006) Tamoxifen paradoxically decreases paclitaxel deposition into cerebrospinal fluid of brain tumor patients. J Neurooncol 76(1):85-92. https://doi.org/ 10.1007/s11060-005-4171-7

Cheung KWK, van Groen BD, Burckart GJ, Zhang L, de Wildt SN, Huang SM (2019) Incorporating ontogeny in physiologically based pharmacokinetic modeling to improve pediatric drug development: what we know about developmental changes in membrane transporters. J Clin Pharmacol 59(Suppl 1):S56-s69. https:// doi.org/10.1002/jcph.1489

Chu X, Zhang Z, Yabut J et al (2012) Characterization of multidrug resistance $1 \mathrm{a} / \mathrm{P}$-glycoprotein knockout rats generated by zinc finger nucleases. Mol Pharmacol 81(2):220-227. https://doi.org/10. 1124/mol.111.074179

Dankovic DA, Naumann BD, Maier A, Dourson ML, Levy LS (2015) The scientific basis of uncertainty factors used in setting occupational exposure limits. J Occup Environ Hyg 12(sup1):55-68. https://doi.org/10.1080/15459624.2015.1060325

Gallo JM, Li S, Guo P, Reed K, Ma J (2003) The effect of P-glycoprotein on paclitaxel brain and brain tumor distribution in mice. Cancer Res 63(16):5114-5117

Gaohua L, Neuhoff S, Johnson TN, Rostami-Hodjegan A, Jamei M (2016) Development of a permeability-limited model of the human brain and cerebrospinal fluid (CSF) to integrate known physiological and biological knowledge: Estimating time varying CSF drug concentrations and their variability using in vitro data. Drug Metab Pharmacokinet 31(3):224-233. https://doi.org/ 10.1016/j.dmpk.2016.03.005

Geyer J, Gavrilova O, Petzinger E (2009) Brain penetration of ivermectin and selamectin in mdrla, b P-glycoprotein- and bcrp- deficient knockout mice. J Vet Pharmacol Ther 32(1):87-96. https://doi.org/ 10.1111/j.1365-2885.2008.01007.x

Haas DW, Stone J, Clough LA et al (2000) Steady-state pharmacokinetics of indinavir in cerebrospinal fluid and plasma among adults with human immunodeficiency virus type 1 infection. Clin Pharmacol Ther 68(4):367-374. https://doi.org/10.1067/mcp.2000. 109391

Harwood MD, Achour B, Neuhoff S, Russell MR, Carlson G, Warhurst G (2016) In vitro-in vivo extrapolation scaling factors for intestinal P-glycoprotein and breast cancer resistance protein: part i: a cross-laboratory comparison of transporter-protein abundances and relative expression factors in human intestine and caco- 2 cells. Drug Metab Dispos 44(3):297-307. https://doi.org/10.1124/dmd. 115.067371

Jackson DV Jr, Sethi VS, Spurr CL, McWhorter JM (1981) Pharmacokinetics of vincristine in the cerebrospinal fluid of humans. Cancer Res 41(4):1466-1468

Jones HM, Mayawala K, Poulin P (2013) Dose selection based on physiologically based pharmacokinetic (PBPK) approaches. Aaps j 15(2):377-387. https://doi.org/10.1208/s12248-012-9446-2 
Kemper EM, van Zandbergen AE, Cleypool C et al (2003) Increased penetration of paclitaxel into the brain by inhibition of P-Glycoprotein. Clin Cancer Res 9(7):2849-2855

Kiki-Mvouaka S, Ménez C, Borin C et al (2010) Role of P-glycoprotein in the disposition of macrocyclic lactones: A comparison between ivermectin, eprinomectin, and moxidectin in mice. Drug Metab Dispos 38(4):573-580. https://doi.org/10.1124/dmd.109.030700

Kim RB, Fromm MF, Wandel C et al (1998) The drug transporter P-glycoprotein limits oral absorption and brain entry of HIV-1 protease inhibitors. J Clin Invest 101(2):289-294. https://doi.org/ 10.1172/jci1269

Kokki M, Välitalo P, Kuusisto M et al (2014) Central nervous system penetration of oxycodone after intravenous and epidural administration. Br J Anaesth 112(1):133-140. https://doi.org/10.1093/ bja/aet337

Krewski D, Acosta D Jr, Andersen M et al (2010) Toxicity testing in the 21st century: a vision and a strategy. J Toxicol Environ Health B Crit Rev 13(2-4):51-138. https://doi.org/10.1080/10937404. 2010.483176

Kumar V, Yin J, Billington S et al (2018) The Importance of Incorporating OCT2 plasma membrane expression and membrane potential in IVIVE of metformin renal secretory clearance. Drug Metab Dispos 46(10):1441-1445. https://doi.org/10.1124/dmd. 118.082313

Kusuhara H, Suzuki H, Terasaki T, Kakee A, Lemaire M, Sugiyama Y (1997) P-Glycoprotein mediates the efflux of quinidine across the blood-brain barrier. J Pharmacol Exp Ther 283(2):574-580

Lam J, Baello S, Iqbal M et al (2015) The ontogeny of P-glycoprotein in the developing human blood-brain barrier: implication for opioid toxicity in neonates. Pediatr Res 78(4):417-421. https:// doi.org/10.1038/pr.2015.119

Lee CG, Gottesman MM, Cardarelli CO et al (1998) HIV-1 protease inhibitors are substrates for the MDR1 multidrug transporter. Biochemistry 37(11):3594-3601. https://doi.org/10.1021/bi972 $709 x$

Li J, Wu J, Bao X et al (2017) Quantitative and Mechanistic understanding of AZD1775 penetration across human blood-brain barrier in glioblastoma patients Using an IVIVE-PBPK modeling approach. Clin Cancer Res 23(24):7454-7466. https://doi.org/10. 1158/1078-0432.Ccr-17-0983

Mahar Doan KM, Humphreys JE, Webster LO et al (2002) Passive permeability and P-glycoprotein-mediated efflux differentiate central nervous system (CNS) and non-CNS marketed drugs. J Pharmacol Exp Ther 303(3):1029-1037. https://doi.org/10.1124/ jpet.102.039255

May TW, Brandt C, Helmer R, Bien CG, Cawello W (2015) Comparison of lacosamide concentrations in cerebrospinal fluid and serum in patients with epilepsy. Epilepsia 56(7):1134-1140. https://doi. org/10.1111/epi.13022

Mayer U, Wagenaar E, Dorobek B, Beijnen JH, Borst P, Schinkel AH (1997) Full blockade of intestinal P-glycoprotein and extensive inhibition of blood-brain barrier P-glycoprotein by oral treatment of mice with PSC833. J Clin Invest 100(10):2430-2436. https:// doi.org/10.1172/jci119784

Moons T, de Roo M, Claes S, Dom G (2011) Relationship between P-glycoprotein and second-generation antipsychotics. Pharmacogenomics 12(8):1193-1211. https://doi.org/10.2217/pgs.11.55

Morris ME, Rodriguez-Cruz V, Felmlee MA (2017) SLC and ABC transporters: expression, localization, and species differences at the blood-brain and the blood-cerebrospinal fluid barriers. Aaps j 19(5):1317-1331. https://doi.org/10.1208/s12248-017-0110-8

Narang PK, Blumhardt CL, Doran AR, Pickar D (1988) Steady-state cerebrospinal fluid transfer of verapamil and metabolites in patients with schizophrenia. Clin Pharmacol Ther 44(5):550-557. https://doi.org/10.1038/clpt.1988.193
Neuhoff S, Yeo KR, Barter Z, Jamei M, Turner DB, Rostami-Hodjegan A (2013a) Application of permeability-limited physiologicallybased pharmacokinetic models: part I-digoxin pharmacokinetics incorporating P-glycoprotein-mediated efflux. J Pharm Sci 102(9):3145-3160. https://doi.org/10.1002/jps.23594

Neuhoff S, Yeo KR, Barter Z, Jamei M, Turner DB, Rostami-Hodjegan A (2013b) Application of permeability-limited physiologicallybased pharmacokinetic models: part II - prediction of P-glycoprotein mediated drug-drug interactions with digoxin. J Pharm Sci 102(9):3161-3173. https://doi.org/10.1002/jps.23607

Nikisch G, Baumann P, Wiedemann G et al (2010) Quetiapine and norquetiapine in plasma and cerebrospinal fluid of schizophrenic patients treated with quetiapine: correlations to clinical outcome and HVA, 5-HIAA, and MHPG in CSF. J Clin Psychopharmacol 30(5):496-503. https://doi.org/10.1097/JCP.0b013e3181f2288e

O'Brien FE, Clarke G, Dinan TG, Cryan JF, Griffin BT (2013) Human P-glycoprotein differentially affects antidepressant drug transport: relevance to blood-brain barrier permeability. Int J Neuropsychopharmacol 16(10):2259-2272. https://doi.org/10.1017/s146114571 3000692

Ochs HR, Greenblatt DJ, Lloyd BL, Woo E, Sonntag M, Smith TW (1980) Entry of quinidine into cerebrospinal fluid. Am Heart J 100(3):341-346. https://doi.org/10.1016/0002-8703(80)90148-9

Paini A, Leonard JA, Joossens E et al (2019) Next generation physiologically based kinetic (NG-PBK) models in support of regulatory decision making. Comput Toxicol 9:61-72. https://doi.org/ 10.1016/j.comtox.2018.11.002

Paulzen M, Gründer G, Tauber SC, Veselinovic T, Hiemke C, Groppe SE (2015) Distribution pattern of mirtazapine and normirtazapine in blood and CSF. Psychopharmacology 232(4):807-813. https:// doi.org/10.1007/s00213-014-3717-9

Paulzen M, Lammertz SE, Gründer G, Veselinovic T, Hiemke C, Tauber SC (2016) Measuring citalopram in blood and cerebrospinal fluid: revealing a distribution pattern that differs from other antidepressants. Int Clin Psychopharmacol 31(3):119-126. https:// doi.org/10.1097/yic.0000000000000114

Piirainen A, Kokki M, Hautajärvi H et al (2016) The cerebrospinal fluid distribution of postoperatively administred dexketoprofen and etoricoxib and their effect on pain and inflammatory markers in patients undergoing hip arthroplasty. Clin Drug Investig 36(7):545-555. https://doi.org/10.1007/s40261-016-0400-4

Pussard E, Merzouk M, Barennes H (2007) Increased uptake of quinine into the brain by inhibition of P-glycoprotein. Eur J Pharm Sci 32(2):123-127. https://doi.org/10.1016/j.ejps.2007.06.007

Rodgers T, Rowland M (2006) Physiologically based pharmacokinetic modelling 2: predicting the tissue distribution of acids, very weak bases, neutrals and zwitterions. J Pharm Sci 95(6):1238-1257. https://doi.org/10.1002/jps.20502

Rodgers T, Leahy D, Rowland M (2005) Physiologically based pharmacokinetic modeling 1: predicting the tissue distribution of moderate-to-strong bases. J Pharm Sci 94(6):1259-1276. https:// doi.org/10.1002/jps.20322

Römermann K, Wanek T, Bankstahl M et al (2013) (R)-[(11)C]verapamil is selectively transported by murine and human P-glycoprotein at the blood-brain barrier, and not by MRP1 and BCRP. Nucl Med Biol 40(7):873-878. https://doi.org/10.1016/j.nucme dbio.2013.05.012

Rose CE, Paciullo CA, Kelly DR, Dougherty MJ, Fleckenstein LL (2009) Fatal outcome of disseminated strongyloidiasis despite detectable plasma and cerebrospinal levels of orally administered ivermectin. J Parasitol Res. https://doi.org/10.1155/2009/818296

Rose RH, Neuhoff S, Abduljalil K, Chetty M, Rostami-Hodjegan A, Jamei M (2014) Application of a physiologically based pharmacokinetic model to predict OATP1B1-Related Variability in Pharmacodynamics of Rosuvastatin. CPT Pharmacometrics Syst Pharmacol 3(7):e124. https://doi.org/10.1038/psp.2014.24 
Sadiq MW, Uchida Y, Hoshi Y, Tachikawa M, Terasaki T, Hammarlund-Udenaes M (2015) Validation of a P-glycoprotein (P-gp) humanized mouse model by integrating selective absolute quantification of human MDR1, Mouse Mdr1a and Mdr1b protein expressions with in vivo functional analysis for blood-brain barrier transport. PLoS ONE 10(5):e0118638. https://doi.org/10. 1371/journal.pone. 0118638

Schinkel AH, Smit JJ, van Tellingen O et al (1994) Disruption of the mouse mdr1a P-glycoprotein gene leads to a deficiency in the blood-brain barrier and to increased sensitivity to drugs. Cell 77(4):491-502. https://doi.org/10.1016/0092-8674(94)90212-7

Schinkel AH, Wagenaar E, van Deemter L, Mol CA, Borst P (1995) Absence of the mdrla P-Glycoprotein in mice affects tissue distribution and pharmacokinetics of dexamethasone, digoxin, and cyclosporin A. J Clin Invest 96(4):1698-1705. https://doi.org/10. 1172/jci118214

Schmitt U, Kirschbaum KM, Poller B et al (2012) In vitro P-glycoprotein efflux inhibition by atypical antipsychotics is in vivo nicely reflected by pharmacodynamic but less by pharmacokinetic changes. Pharmacol Biochem Behav 102(2):312-320. https:// doi.org/10.1016/j.pbb.2012.04.002

Shawahna R, Uchida Y, Declèves X et al (2011) Transcriptomic and quantitative proteomic analysis of transporters and drug metabolizing enzymes in freshly isolated human brain microvessels. Mol Pharm 8(4):1332-1341. https://doi.org/10.1021/mp200129p

Shebley M, Sandhu P, Emami Riedmaier A et al (2018) physiologically based pharmacokinetic model qualification and reporting procedures for regulatory submissions: a consortium perspective. Clin Pharmacol Ther 104(1):88-110. https://doi.org/10.1002/cpt.1013

Skogh E, Sjödin I, Josefsson M, Dahl ML (2011) High correlation between serum and cerebrospinal fluid olanzapine concentrations in patients with schizophrenia or schizoaffective disorder medicating with oral olanzapine as the only antipsychotic drug. J Clin Psychopharmacol 31(1):4-9. https://doi.org/10.1097/JCP.0b013 e318204d9e2

Syvänen S, Lindhe O, Palner M et al (2009) Species differences in blood-brain barrier transport of three positron emission tomography radioligands with emphasis on P-glycoprotein transport. Drug Metab Dispos 37(3):635-643. https://doi.org/10.1124/dmd. 108.024745

Tanino T, Nawa A, Nakao M, Noda M, Fujiwara S, Iwaki M (2009) Organic anion transporting polypeptide 2-mediated uptake of paclitaxel and 2'-ethylcarbonate-linked paclitaxel in freshly isolated rat hepatocytes. J Pharm Pharmacol 61(8):1029-1035. https://doi.org/10.1211/jpp/61.08.0006

ten Tije AJ, Loos WJ, Zhao M et al (2004) Limited cerebrospinal fluid penetration of docetaxel. Anticancer Drugs 15(7):715-718. https://doi.org/10.1097/01.cad.0000136882.19552.8f

Uchida Y, Ohtsuki S, Katsukura Y et al (2011) Quantitative targeted absolute proteomics of human blood-brain barrier transporters and receptors. J Neurochem 117(2):333-345. https://doi.org/10. $1111 / j .1471-4159.2011 .07208 . x$

Uhr M, Grauer MT (2003) abcb1ab P-glycoprotein is involved in the uptake of citalopram and trimipramine into the brain of mice. J Psychiatr Res 37(3):179-185. https://doi.org/10.1016/s00223956(03)00022-0

Uhr M, Grauer MT, Holsboer F (2003) Differential enhancement of antidepressant penetration into the brain in mice with abcb1ab (mdr1ab) P-glycoprotein gene disruption. Biol Psychiatry 54(8):840-846. https://doi.org/10.1016/s0006-3223(03)00074-x

Verscheijden LFM, Koenderink JB, de Wildt SN, Russel FGM (2019) Development of a physiologically-based pharmacokinetic pediatric brain model for prediction of cerebrospinal fluid drug concentrations and the influence of meningitis. PLoS Comput Biol 15(6):e1007117. https://doi.org/10.1371/journal.pcbi.1007117

Verscheijden LFM, Koenderink JB, Johnson TN, de Wildt SN, Russel FGM (2020) Physiologically-based pharmacokinetic models for children: Starting to reach maturation? Pharmacol Ther. https:// doi.org/10.1016/j.pharmthera.2020.107541

Verscheijden LFM, van Hattem AC, Pertijs J et al (2020b) Developmental patterns in human blood-brain barrier and blood-cerebrospinal fluid barrier ABC drug transporter expression. Histochem Cell Biol. https://doi.org/10.1007/s00418-020-01884-8

Verscheijden LFM, Litjens CHC, Koenderink JB et al (2021) Physiologically based pharmacokinetic/pharmacodynamic model for the prediction of morphine brain disposition and analgesia in adults and children. PLoS Comput Biol 17(3):e1008786. https://doi.org/ 10.1371/journal.pcbi.1008786

Wang JS, Taylor R, Ruan Y, Donovan JL, Markowitz JS, Lindsay De Vane C (2004) Olanzapine penetration into brain is greater in transgenic Abcb1a P-glycoprotein-deficient mice than FVB1 (wild-type) animals. Neuropsychopharmacology 29(3):551-557. https://doi.org/10.1038/sj.npp.1300372

Wang F, Zhou F, Kruh GD, Gallo JM (2010) Influence of blood-brain barrier efflux pumps on the distribution of vincristine in brain and brain tumors. Neuro Oncol 12(10):1043-1049. https://doi.org/10. 1093/neuonc/noq056

Weaver RJ, Valentin JP (2019) Today's Challenges to De-Risk and Predict Drug Safety in Human "Mind-the-Gap." Toxicol Sci 167(2):307-321. https://doi.org/10.1093/toxsci/kfy270

Xia CQ, Xiao G, Liu N et al (2006) Comparison of species differences of P-glycoproteins in beagle dog, rhesus monkey, and human using Atpase activity assays. Mol Pharm 3(1):78-86. https://doi. org/10.1021/mp050034j

Xie R, Hammarlund-Udenaes M, de Boer AG, de Lange EC (1999) The role of P-glycoprotein in blood-brain barrier transport of morphine: transcortical microdialysis studies in mdr1a (-/-) and mdr1a (+/+) mice. Br J Pharmacol 128(3):563-568. https://doi.org/10. 1038/sj.bjp.0702804

Yamamoto Y, Välitalo PA, Huntjens DR et al (2017) Predicting drug concentration-time profiles in multiple CNS compartments using a comprehensive physiologically-based pharmacokinetic model. CPT Pharmacometrics Syst Pharmacol 6(11):765-777. https:// doi.org/10.1002/psp4.12250

Yamazaki M, Neway WE, Ohe T et al (2001) In vitro substrate identification studies for p-glycoprotein-mediated transport: species difference and predictability of in vivo results. J Pharmacol Exp Ther 296(3):723-735

Zolnerciks JK, Booth-Genthe CL, Gupta A, Harris J, Unadkat JD (2011) Substrate- and species-dependent inhibition of P-glycoprotein-mediated transport: implications for predicting in vivo drug interactions. J Pharm Sci 100(8):3055-3061. https://doi.org/10. 1002/jps.22566

Publisher's Note Springer Nature remains neutral with regard to jurisdictional claims in published maps and institutional affiliations. 